\section{Weed Suppression Potential of Living Mulches, Newspaper Hydromulches, and Compost Blankets in Organically Managed Carrot Production}

\author{
Jesse Puka-Beals ${ }^{1}$ and Greta Gramig ${ }^{1}$
}

\begin{abstract}
ADDITIONAL INDEX WORDs. biodegradable, newsprint, hemp, strip-tillage, weed/ crop interference, weed community shift, small-scale

SUMMARY. Direct seeding into strip-tilled zones (STZs) of living mulches may require weed suppression tactics for soil surfaces exposed within the STZ. Three surface mulch options (hydromulch, compost blanket, and a no-mulch control) were evaluated for their ability to suppress weeds and improve crop performance when applied in STZs seeded to carrot (Daucus carota). These STZs were located within one of five living mulch options [red clover (Trifolium pratense), white clover (Trifolium repens), perennial ryegrass (Lolium perenne), a weed-free control, and a weedy control]. From measurements spanning 2 years at two North Dakota locations, dry weed biomass was lower in STZs where hydromulch or compost blankets were applied compared with the no-mulch control $\left(12,13\right.$, and $82 \mathrm{~g} \cdot \mathrm{m}^{-2}$, respectively). The presence of a living mulch adjacent to the STZ reduced carrot root biomass by $49 \%$ to $84 \%$ compared with the weed-free control. Further research should 1) investigate methods for reducing yield loss from living mulches, and 2) develop biodegradable alternatives to plastic mulches.
\end{abstract}

$\mathrm{V}$ egetable growers and researchers acknowledge the need for additional weed control tools and tactics (DeDecker et al., 2014; Jerkins and Ory, 2016). For organic vegetable production systems, living mulches are attractive for combined weed control and soil benefits (Kołota and Adamczewska-Sowińska, 2013). Yet efforts to integrate living mulches with vegetable crops often result in substantial yield reduction from resource competition (Pfeiffer et al., 2016; Pieper et al., 2015). Strip-tilling into living mulches and then direct seeding a vegetable crop may limit yield

Received for publication 29 Sept. 2020. Accepted for publication 4 Dec. 2020

Published online 11 January 2021

${ }^{1}$ Department of Plant Sciences, North Dakota State University, 1360 Albrecht Boulevard N, Fargo, ND 58102

We thank Kris Boll, Derick Crespo-Hernandez, and Kenneth Paul Beamer for their technical assistance. We thank Ross and Amber Lockhart of Heart and Soil Farm for collaborating on this project. We also thank Dr. Alan Zuk and Dr. Harlene Hatterman-Valenti for their comments on the manuscript.

This research was supported by USDA-Hatch Project \# ND01583, North Dakota Specialty Crop Block Grant \# 17-372 and North Dakota EPSCoR.

J.P.-B. is the corresponding author. E-mail: jesse. pukabeals@ndsu.edu.

This is an open access article distributed under the CC BY-NC-ND license (https://creativecommons.org/ licenses/by-nc-nd/4.0/).

https://doi.org/10.21273/HORTTECH04745-20 reductions by limiting competition between the living mulch and vegetable crop (Masiunas, 1998). However, a secondary weed control tactic may be required to control weeds within the strip-till zone.

Surface-applied mulches provide weed control by forming a physical weed-suppressive barrier over the soil surface. Nondegradable polyethylene plastic is the most widely used surface-applied mulch material and biodegradable alternatives are needed (Goldberger et al., 2015; Wortman et al., 2016). Of the commercially available biodegradable alternatives, concerns over their degradation and allowability in organic systems remain a barrier for adoption (Miles et al., 2017). Some biodegradable materials also may be more appropriate for vegetable crops that cannot be transplanted and prefer cooler soil temperatures like carrot (Daucus carota). Carrot has a long critical weed-free period (450 930 growing degree days) and very limited weed control options (Swanton et al., 2010). In organically managed small-scale vegetable production around Fargo, ND, the costs of controlling weeds and purchasing fertilizers to maintain soil fertility are significant and the outcomes of adopting living mulches and biodegradable surface-applied mulches are not well known.

To address these challenges, we adapted two erosion control tactics described in Faucette et al. (2006), hydromulching and compost blankets, and applied them as surface mulches for weed control. Hydromulching involves suspending a mulch material in water so that it can be applied as a liquid on the soil surface before hardening into a physical barrier. Efforts to combine newspaper and other by-products into an agricultural hydromulch have previously provided $57 \%$ to $63 \%$ weed suppression, while also promoting advantageous soil conditions for cool-season crops (Warnick et al., 2006). Compost blankets consist of composted weed-free organic materials applied onto the soil surface to reduce weed emergence. Unlike straw or bark mulches, compost blankets may have sufficient soil-like physical properties (e.g., porosity, water infiltration) and fertility to be direct seeded into and support initial crop growth. Most commercially available surface mulches used for weed suppression are either not designed to be applied in a liquid form or do not serve as a crop growing medium. We investigated weed, crop, and soil responses to surface mulches applied in strip-till zones within plots of living mulches.

\begin{tabular}{llll}
\hline $\begin{array}{l}\text { Units } \\
\text { To convert U.S. to SI, } \\
\text { multiply by }\end{array}$ & U.S. unit & SI unit & $\begin{array}{l}\text { To convert SI to U.S., } \\
\text { multiply by }\end{array}$ \\
\hline 0.3048 & $\mathrm{ft}$ & $\mathrm{m}$ & 3.2808 \\
0.0929 & $\mathrm{ft}$ & $\mathrm{m}^{2}$ & 10.7639 \\
3.7854 & $\mathrm{gal}$ & $\mathrm{L}$ & 0.2642 \\
12.4193 & $\mathrm{gal} / \mathrm{ft}$ & $\mathrm{L} \cdot \mathrm{m}^{-1}$ & 0.0805 \\
40.7458 & $\mathrm{gal} / \mathrm{ft}^{2}$ & $\mathrm{~L} \cdot \mathrm{m}^{-2}$ & 0.0245 \\
2.54 & inch $(\mathrm{es})$ & $\mathrm{cm}$ & 0.3937 \\
25.4 & inch $(\mathrm{es})$ & $\mathrm{mm}$ & 0.0394 \\
0.4536 & $\mathrm{lb}$ & $\mathrm{kg}$ & 2.2046 \\
1.1209 & $\mathrm{lb} / \mathrm{acre}$ & $\mathrm{kg} \cdot \mathrm{ha}^{-1}$ & 0.8922 \\
305.1517 & $\mathrm{oz} / \mathrm{ft}^{2}$ & $\mathrm{~g} \cdot \mathrm{m}^{-2}$ & 0.0033 \\
$\left({ }^{\circ} \mathrm{F}-32\right) \div 1.8$ & ${ }^{\circ} \mathrm{F}$ & ${ }^{\circ} \mathrm{C}$ & $\left({ }^{\circ} \mathrm{C} \times 1.8\right)+32$ \\
& & &
\end{tabular}

Hortlechnology $\cdot$ February $202131(1)$ 
Table 1. Mean monthly air temperature and precipitation in Absaraka, ND, and Fargo, ND, during the 2018 and 2019 growing seasons for the carrot-mulch experiment as reported by the North Dakota Agricultural Weather Network.

\begin{tabular}{|c|c|c|c|c|c|c|}
\hline \multirow[b]{3}{*}{ Location/month } & \multicolumn{3}{|c|}{$\begin{array}{c}\text { Mean } \\
\text { air temp }\end{array}$} & \multicolumn{3}{|c|}{$\begin{array}{c}\text { Mean total } \\
\text { precipitation }\end{array}$} \\
\hline & Normal $^{z}$ & 2018 & 2019 & Normal $^{\mathrm{y}}$ & 2018 & 2019 \\
\hline & \multicolumn{3}{|c|}{$\ldots \ldots \ldots \ldots \ldots$} & \multicolumn{3}{|c|}{${ }^{\prime} \ldots \ldots \ldots \ldots$} \\
\hline \multicolumn{7}{|l|}{ Absaraka } \\
\hline May & 13.4 & 16.8 & 10.6 & 77.5 & 53.9 & 60.0 \\
\hline June & 19.7 & 20.5 & 19.2 & 101.1 & 80 & 122.0 \\
\hline July & 21.3 & 20.3 & 21.9 & 87.6 & 65 & 156.1 \\
\hline August & 20.4 & 19.4 & 18.4 & 66.6 & 78.5 & 102.4 \\
\hline September & 14.8 & 14.1 & 15.5 & 65.5 & 70.9 & 147.7 \\
\hline \multicolumn{7}{|l|}{ Fargo } \\
\hline May & 13.9 & 17.9 & 11.4 & 71.3 & 43.6 & 69.6 \\
\hline June & 19.0 & 21.4 & 19.7 & 99.1 & 123.2 & 82.8 \\
\hline July & 21.6 & 21.9 & 22.5 & 70.9 & 80.9 & 121.3 \\
\hline August & 20.7 & 20.8 & 19.8 & 65.0 & 100.9 & 89.7 \\
\hline September & 15.0 & 14.9 & 16.9 & 65.1 & 64.4 & 106.8 \\
\hline
\end{tabular}

${ }^{\mathrm{z}}$ Mean air temperature between 1980 and $2010 ;\left(1.8 \times{ }^{\circ} \mathrm{C}\right)+32={ }^{\circ} \mathrm{F}$.

${ }^{y}$ Mean total precipitation between 1980 and $2010 ; 1 \mathrm{~mm}=0.0394$ inch.

We hypothesized that weed density and biomass would be reduced by perennial living mulches, although the extent to which harsh winters in North Dakota would impact performance was unknown (Chase and Mbuya, 2008; Kołodziejczyk, 2015; Osipitan et al., 2018). Competition from living mulches was expected to reduce carrot yield, but we hypothesized that the use of strip-tillage will limit yield reductions compared with the $67 \%$ to $100 \%$ yield reductions observed when strip-tillage was not combined with living mulches (Pfeiffer et al., 2016). We also hypothesized that, in comparison with grass living mulches, soil fertility would be improved during production by using a leguminous (Fabaceae) living mulch, such as clover [Trifolium sp. (Carlsson and HussDanell, 2003)]. Last, we hypothesized that hydromulch and compost blanket treatments would reduce weed density and weed biomass in the strip-till zone by adding an additional physical impedance to emerging weeds (Teasdale and Mohler, 2000).

\section{Materials and methods}

Field experiments were conducted at the North Dakota State University (NDSU) Horticulture research farm in Absaraka, ND (lat. $46^{\circ} 59^{\prime} 16.1 \mathrm{~N}$, long. $97^{\circ} 21^{\prime} 08.6$ $\mathrm{W}$ ), and at the NDSU main Agriculture Experiment Station in Fargo, $\mathrm{ND}$ (lat. $46^{\circ} 53^{\prime} 38.4 \mathrm{~N}$, long. $96^{\circ} 48^{\prime} 37.8 \mathrm{~W}$ ), during 2018 and
2019. The field in Absaraka, ND, was certified organic in 2015 , the field in Fargo, ND, was not certified organic. Soils were predominantly Warsing Loam at the Absaraka site and Fargo Silty Clay at the Fargo site. In Apr. 2018, both sites were weeded by hand using spading forks to remove minor infestations of field bindweed (Convolvulus arvensis) and canada thistle (Cirsium arvense) and were then rototilled. Dry, pelletized, composted poultry manure $(4 \mathrm{~N}-$ $1.3 \mathrm{P}-1.7 \mathrm{~K})$ was broadcast at a rate to achieve $100 \mathrm{~kg} \cdot \mathrm{ha}^{-1}$ nitrogen $[\mathrm{N}$ (Cashton Farm Supply, Cashton, WI)]. The composted poultry manure was then tractor incorporated using a double-action disc harrow with plain coulter blades at the Absaraka site (3600; Ford Motor Co., Detroit, MI) and a walk-behind tractor $(749$; BCS America, Portland, $\mathrm{OR}$ ) with a power harrow (R2 Rinaldi; Ciampelli, Corsalone, Italy) at the Fargo site. Weather conditions for both years are summarized in Table 1.

Research plots were $5 \mathrm{ft}$ wide and $15 \mathrm{ft}$ long and arranged in a twofactor randomized complete block design with four replications. Plots first received one of five living mulch options: red clover (Trifolium pratense), white clover (Trifolium repens), perennial ryegrass (Lolium perenne), a weed-free control, and a weedy control. The weed-free control was cultivated and hand-weeded at least every 2 weeks throughout the season to eradicate all weeds. The weedy control was left unmanaged. Seeding rates were $15 \mathrm{lb} /$ acre for all three living mulch species. White clover and red clover were inoculated (Pre-Vail Alfalfa/True Clover Combination; Verdesian Life Sciences, Cary, NC) to enhance N-fixation via rhizobia (Sinorhizobium meliloti, Rhizobium leguminosarum biovar trifolii). Living mulch seed was broadcasted by hand with an oat (Avena sativa) nurse crop at a rate of $32 \mathrm{lb} /$ acre. Living mulches were hand-weeded and reseeded by hand 2 weeks after the initial seeding because atypically hot and dry weather impaired living mulch establishment. One month after living mulch seeding, strip-till zones were created in the center of each plot at a width of 9 inches using a rototiller (FGl10; Honda, Torrance, CA). Strip-till zones were raked to remove debris and ensure a flat seedbed for carrot planting and surface mulch application. Rototilling and raking the striptill zones were repeated in 2019 before planting.

Plots received one of three surface mulch options applied in the strip-till zones: hydromulch, compost blanket, and a no-mulch control. The hydromulch was made by mixing shredded newsprint (S-1079; Uline, Pleasant Prairie, WI) and water at a ratio of $1 \mathrm{~kg}$ of paper to $35 \mathrm{~L}$ of water. The newspaper and water were combined using a hydroseed mixer (HS-100; TurboTurf, Beaver Falls, PA). Mixing continued until a homogenized slurry formed, usually 
requiring $10 \mathrm{~min}$ on high power for the hydroseed mixer engine. A steel C-channel bar $\approx 4 \mathrm{~cm}$ wide and $16 \mathrm{ft}$ long was placed over the carrot planting zone within the strip-till zone after the carrot was planted and before the hydromulch was applied. The rationale for using the $\mathrm{C}$-channel bar was to maintain a slit of bare soil in the strip-till zone for the carrot crop to emerge through (Fig. 1). Hydromulch was gravity fed from a modified 4-gal backpack sprayer (60100; Chapin, Chapin, NY) onto the soil at an application rate of $12.7 \mathrm{~L} \cdot \mathrm{m}^{-2}$ within the strip-till zone, which is the equivalent of $\approx 4$ gal of hydromulch per strip-till zone. Hydromulch application tubes were kept less than 2 inches above the soil surface to reduce disturbance of the freshly tilled soil in the strip-till zone. The hydromulch mixture was left to dry for $1 \mathrm{~min}$ after application before the C-channel bar was removed. Typical thickness of the wet hydromulch mixture was $2 \mathrm{~cm}$ immediately after application and between 0.3 and $0.5 \mathrm{~cm}$ after drying. The compost blanket consisted of hemp (Cannabis sativa) hurd and composted cow manure in a 2:1 ratio by volume and was applied at a rate of $108 \mathrm{~L} \cdot \mathrm{m}^{-2}$ in the strip-till zone, or $\approx 30$ gal of material per strip-till zone. The hemp hurd was a by-product of hemp production and contained cellulose ( $44 \%$ to $55 \%$ ), hemicelluloses (16\% to $18 \%$ ), and lignin ( $4 \%$ to $28 \%$ ) (DunAgro, Oude Pekela, Netherlands). The composted cow manure was sourced from a dairy farm that

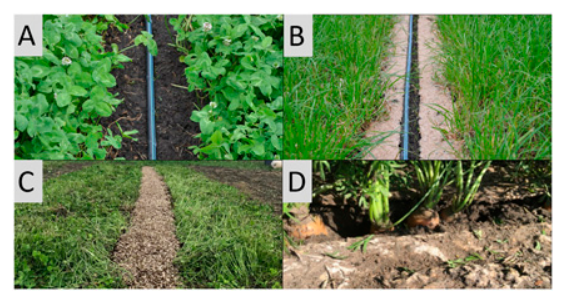

Fig. 1. Three images of plots within the experiment where $(A)$ is a plot with white clover and a no-mulch strip-till zone, where $(B)$ is a plot with perennial ryegrass and

a hydromulched strip-till zone, where

(C) is a plot with red clover and compost blanketed strip-till zone, and (D) is a plot with carrots emerging in a strip-till zone with hydromulch.

Images (A-C) were taken 1 week after planting the carrot crop in 2019.

Image (D) was taken in Aug. 2018. was managed in compliance with $\mathrm{Na}$ tional Organic Program regulation 205.203 (Cowsmo, Cochrane, WI). Compost blankets were applied and compressed by hand using a wooden board that would be placed on top of the loose compost blanket and then two people would walk on the board for $\approx 1$ min to help the materials settle. The approximate thickness of the compost blanket was 5 inches. Both the hydromulch and compost blanket treatments applied in 2018 were removed from plots in Spring 2019 and reapplied for the 2019 growing season. The carbon-to- $\mathrm{N}$ ratios $(\mathrm{C}: \mathrm{N})$ of the surface mulches were 121:1 for the hydromulch and 41:1 for the compost blanket.

Carrot was seeded directly into the soil for the hydromulch and nomulch treatments and into the compost blanket for the compost blanket treatments. Carrot was seeded in a single row at a depth of 0.25 to 0.5 inch and a rate of 48 seeds/ $\mathrm{ft}$ using a single-row precision push seeder (JP-1; JangAutomation, Seoul, Korea). Drip tape was installed after planting using a medium flow drip tape with emitter spacing of 4 inches and an output of $7.4 \mathrm{~L} \cdot \mathrm{m}^{-1}$ per hour (TDE804100; Dripworks, Willits CA). In the first 2 weeks after carrot seeding, strip-till zones were watered daily for $2 \mathrm{~h}$ in the morning and $\mathrm{l} \mathrm{h}$ in the afternoon. The following 2 weeks, carrots were watered $4 \mathrm{~d}$ per week for $2 \mathrm{~h}$ in the morning. Irrigation ceased after week 4. Living mulches were mowed throughout both growing seasons to reduce aboveground interference with the carrot crop, every $\approx 2$ weeks. Mowing height was $10 \mathrm{~cm}$ and was accomplished using a wheeled string trimmer (25A-262J756; Cub Cadet, Cleveland, $\mathrm{OH}$ ) at the Fargo site and a deck mower (Z121S-48; Kubota Tractor Corp., Grapevine, TX) at the Absaraka site. Living mulch aboveground biomass that still encroached into the strip-till zone after mowing was removed by hand. Plant debris from mowing was not removed from the plots, except during the first mowing of the 2019 growing season, where plant height in red clover treatments at the Absaraka site was too high $(\approx 70 \mathrm{~cm})$ for effective mowing with the deck mower and required subsequent hand cutting and removal of aboveground biomass to support regrowth.
Minimal amounts of living mulch biomass would blow out of the living mulch zone and into the adjacent strip-till zone or alleys during mowing. Experimental dates for all principal field activities are provided in Table 2 and images of plots are provided in Fig. 1.

Weed community assessments were conducted in the strip-till zone and living mulch zone around peak weed biomass accumulation (Table 2 ). Four quadrats were systematically placed in both the strip-till zone $\left(0.0175 \mathrm{~m}^{2}\right)$ and living mulch zone $\left(0.0625 \mathrm{~m}^{2}\right)$ to estimate the weed populations. Weeds were removed from quadrats, separated by species, washed, counted, and then dried to constant weight in an oven $\left(\approx 70{ }^{\circ} \mathrm{C}\right)$ before being weighed to determine biomass. Carrots were assessed immediately after emergence and at harvest (Table 2). Emerged carrots were counted in two $1-\mathrm{ft}$ samples along the 15 - $\mathrm{ft}$ length of carrot row in the strip-till zone. Carrots were then thinned to 2-inch spacing, which should have resulted in $\approx 20$ plants/ $\mathrm{m}$, but inconsistent emergence resulted in stand densities of $15.2 \pm$ 0.7 carrots $/ \mathrm{m}$ at Absaraka and $8.6 \pm$ 0.6 carrots $/ \mathrm{m}$ at Fargo. At harvest, all carrots were harvested and fresh biomass of roots was determined. Soil samples were taken at the beginning and end of the experiment to assess the effect of living mulches on soil nitrate content during the duration of the experiment. Each plot was sampled by taking 10 cores in a systematic zig-zag pattern in the living mulch area at a depth of 0 to $15 \mathrm{~cm}$ using a soil probe with an inside diameter of $5 / 8$ inch (AMS, American Falls, ID). Soil cores were then homogenized and sent to NDSU soil testing laboratory for determination of soil nitrate content (Vendrell and Zupancic, 1990).

Statistical analysis. All univariate responses were analyzed using PROC GLIMMIX (SAS version 9.4; SAS Institute, Cary, NC). Model effects were a full factorial of surface mulch and living mulch. Efforts were made to detect main effects across years using a repeated measures statement. Multiple computational methods, covariance structures, and distributions within GLIMMIX were evaluated for acceptable fit statistics by their proximity to $l$ for the $\chi^{2}$ divided by degrees of 
Table 2. Dates of principal field activities for executing the carrot-mulch experiment in Absaraka, ND, and Fargo, ND, in 2018 and 2019.

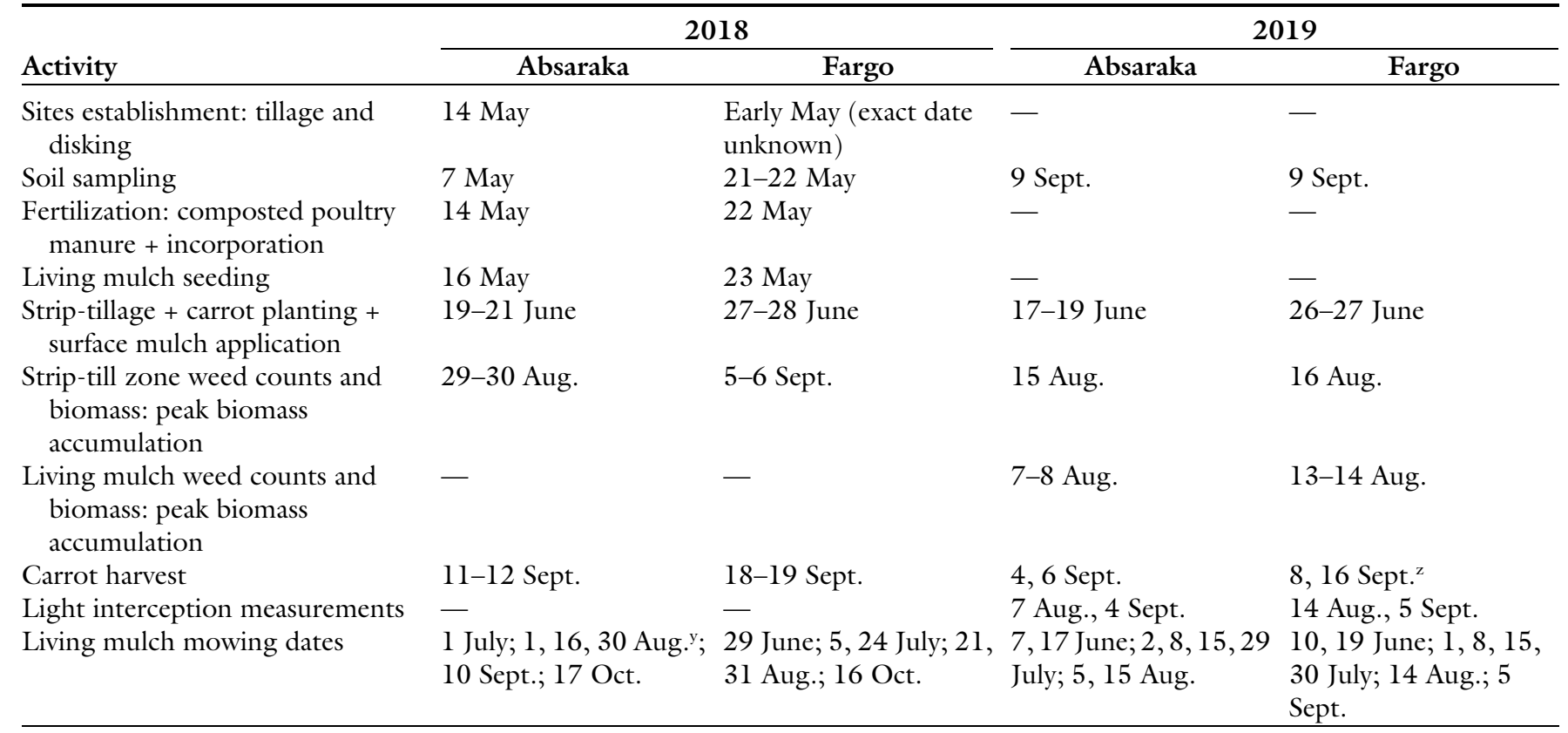

${ }^{\mathrm{z} B}$ Block 1 was harvested on 8 Sept., but the remaining blocks could not be harvested until 16 Sept. due to wet field conditions.

${ }^{y}$ Living mulches at both sites were mowed using a wheeled string trimmer until 30 Aug. 2018, when a deck mower replaced the push mower at Absaraka, ND, for the remainder of the experiment.

freedom (Schabenberger, 2005). Despite carrot thinning, total carrot biomass was confounded by the variability in total carrot counts as can occur with direct-seeded crops (Reid et al., 2018). Although an acceptable model was achieved using total carrot biomass as a response and total carrot count as a covariate, average carrot biomass (total carrot biomass $\div$ total carrot count) presented similar results and with a better model fit, so average carrot biomass was selected as a proxy for the yield response. The 2018 soil nutrient data were analyzed to detect potential artifact spatial differences in fertility at each location. The 2019 soil nutrient data were log-transformed before analysis to achieve acceptable fit statistics. Logtransformed means were compared using Tukey's honestly significant differences $(\alpha=0.05)$.

Weed community composition was analyzed using the vegan package in $\mathrm{R}$ ( $\mathrm{R}$ Development Core Team, Ames, IA) (Oksanen et al., 2010). Nonmetric multidimensional scaling was used to determine ecological distance between weed counts and multiple distance metrics were compared for their appropriateness, reliability, and robustness (Clarke et al., 2006; Faith et al., 1987). Ultimately, all ordinations detected the same differences in weed communities due to experimental treatments and an ordination with Bray-Curtis, two dimensions, and stress levels below 0.2 were selected for presenting weed community dissimilarities among treatments. Of the 240 total plot observations, 37 plots did not contain any weeds and were therefore removed from the ordination using Bray-Curtis (Oksanen et al., 2010). To further clarify the presentation of ecological distance among weed species within the strip-till zone, uncommon weed species were ultimately grouped into a "broadleaf" or "grass" category along with the three most abundant broadleaf species [common purslane (Portulaca oleracea), redroot pigweed (Amaranthus retroflexus), and venice mallow (Hibiscus trionum)] and the three most abundant grass species [barnyardgrass (Echinochloa crus-galli), yellow foxtail (Setaria pumila), and stinkgrass (Eragrostis cilianensis)]. Only weed species with annual life cycles were compared because many perennial weeds were removed by hand before the experiment. Surface mulch treatments were fitted onto the ordination as environmental effects and pairwise comparisons were conducted to determine whether differences in weed community composition existed among the experimental treatments (Oksanen et al., 2010).

\section{Results and discussion}

WeEDS. In the strip-till zones, weed biomass was lower with hydromulch and compost blanket compared with the no-mulch control (Fig. 2). Weed biomass was also lower in strip-till zones adjacent to living mulches compared with strip-till zones adjacent to weed-free controls (Fig. 3). The reduction in strip-till zone weed biomass was unaffected by the adjacent living mulch species. In the living mulch area, weed biomass reductions were not consistent across both locations (Fig. 4). Excellent weed suppression was observed in the white clover (99\%) and perennial ryegrass $(97 \%)$ treatments at Absaraka, compared with an $81 \%$ reduction in the red clover treatment. In contrast, excellent weed suppression was observed in the white clover (99\%) and red clover (96\%) treatments at Fargo, and only fair weed suppression was observed in the perennial ryegrass (69\%). Grassy weed species were more abundant in the compost blanket treatment within the strip-till zone compared with the hydromulch and no-mulch weed communities (Fig. $5)$. 


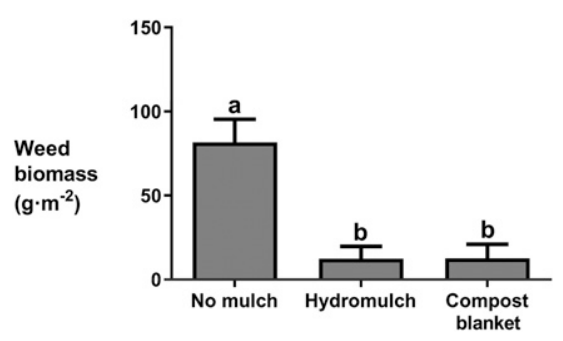

Fig. 2. Weed biomass in the strip-till zone at peak biomass accumulation among surface mulches at Absaraka, ND, and Fargo, ND, during 2018 and 2019. Strip-till zones were planted to carrot. Bars represent the mean, and error bars represent the SE. Bars with the same letters do not differ according to Tukey's honestly significant difference $(\alpha=0.05)$; $1 \mathrm{~g} \cdot \mathrm{m}^{-2}=0.0033 \mathrm{oz} / \mathrm{ft}^{2}$.

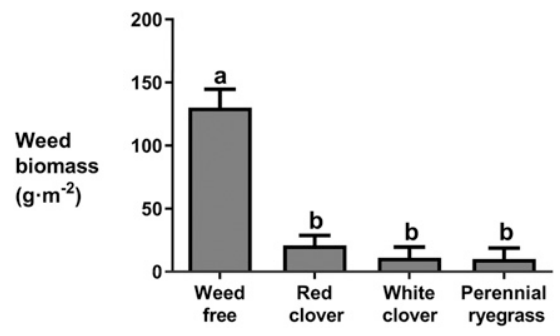

Fig. 3. Weed biomass in the strip-till zones within different living mulch treatments at peak biomass accumulation in Absaraka, ND, and Fargo, ND, during 2018 and 2019. Strip-till zones were planted to carrot. Bars represent the mean, and error bars represent the SE. Bars with the same letters do not differ according to Tukey's honestly significant difference $(\alpha=0.05) ; 1 \mathrm{~g} \cdot \mathrm{m}^{-2}=$ $0.0033 \mathrm{oz} / \mathrm{ft}^{2}$.

Weed biomass reduction provided by the hydromulch and compost blanket was not surprising because materials that provide physical impedance reduce weed emergence (Teasdale and Mohler, 2000). More surprising was the similarity of weed biomass reduction in the hydromulch and compost blanket treatments because the newspaper hydromulch is similar to a landscape fabric with a high area-to-mass ratio and a low solid volume fraction, whereas a compost blanket is similar to bark mulch with a low area-to-mass ratio and a high solid volume fraction. Teasdale and Mohler (2000) demonstrated how mulches differing in areato-mass ratios and solid volume fraction also differ in weed control by virtue of differences in soil coverage and strength. Weeds typically face less physical impedance when emerging from below a mulch like a compost blanket compared with a hydromulch, but the thicker compost blanket application may explain the similar levels of weed biomass reduction control because a weed that did emerge in the compost blanket needed to grow 5 inches in low light conditions before being able to photosynthesize at an efficient rate. Many annual weed species may not have enough stored energy in their seeds to grow through the compost blanket, especially broadleaf weeds that lack a coleoptile to penetrate through mulches. As a result, more weeds may have germinated under the compost blankets than were observed, because these weeds died within the low light conditions of the compost blanket while emerging. Weed community shifts away from broadleaf weeds in compost blanket strip-till zones provide further support that more weeds may have started to germinate in the compost blanket treatments but were not able to emerge because of prolonged low light exposure or physical impedance.

Resource competition likely explains weed biomass reductions in both the living mulches and the strip-till zones adjacent to living mulches. Differences in weed biomass reductions by location may be attributable to the influence of differing soil conditions on living mulch tolerance to mowing and winterhardiness. At Absaraka, the loam soil supported more robust vegetative growth than the Fargo clay, resulting in taller stands of red clover before the first mowing in 2019. The tall height of red clover resulted in considerably more biomass within the living mulches after mowing, which hindered red clover regrowth more in Absaraka where red clover height had been greater than in Fargo. Perennial ryegrass provided the least amount of weed suppression at Fargo compared with Absaraka, possibly because of winterkill between 2018 and 2019 (data not shown). Overall, the weed suppression provided by the living mulches was far greater than the results provided in previous studies, which ranged from $1 \%$ to $67 \%$ (Gruszecki et al., 2015; Ross et al., 2001).
One possible explanation for the comparably higher levels of weed control and weed suppression observed at peak biomass accumulation in 2019 is the combination of ensuring a robust establishment of the living mulches in 2018 and the high frequency of mowing in 2019.

YIELD. Carrot biomass was lower when grown adjacent to living mulches compared with the weedfree controls (Fig. 6). Yield reduction was lowest with white clover and greatest with perennial ryegrass. Carrot biomass reductions were lower when a compost blanket was present in the strip-till zone compared with the no-mulch control (Fig. 7).

Aboveground resource competition for light was expected to occur if mowing was not timely. In 2018, mowing was less consistent and carrot yield reductions were large among living mulch treatments. In 2019, mowing was timelier. Light measurements were taken in the strip-till zone using a ceptometer both before and after mowing and indicated mowing increased the amount of $P A R$ reaching the carrot leaves by $134 \pm 25$ $\mu \mathrm{mol} \cdot \mathrm{m}^{-2} \cdot \mathrm{s}^{-1}$ (data not shown). Despite timelier mowing, the yield reduction in the living mulch treatments remained consistent in 2019, as evidenced by our statistical ability to combine the 2 years of carrot biomass percent reduction observations. Resource competition from living mulches, therefore, likely occurred primarily belowground, which is consistent with observations in Pfeiffer et al. (2016) and Gruszecki et al. (2015).

Carrot biomass reductions in this experiment ranged from $49 \%$ to $84 \%$, which is lower than the $67 \%$ to $100 \%$ yield reductions reported by Pfeiffer et al. (2016), suggesting the use of strip-tillage did limit resource competition. However, our biomass reductions were greater than other similar experiments. For example, Gruszecki et al. (2015) reported an $18 \%$ to $26 \%$ total carrot yield reduction. They also used ridge tillage to manage competition rather than strip-tillage, possibly explaining their lower yield reduction results.

Although carrot biomass reductions were lower when the compost blanket was applied in the strip-till zone compared with the no-mulch control, the difference accounted for 


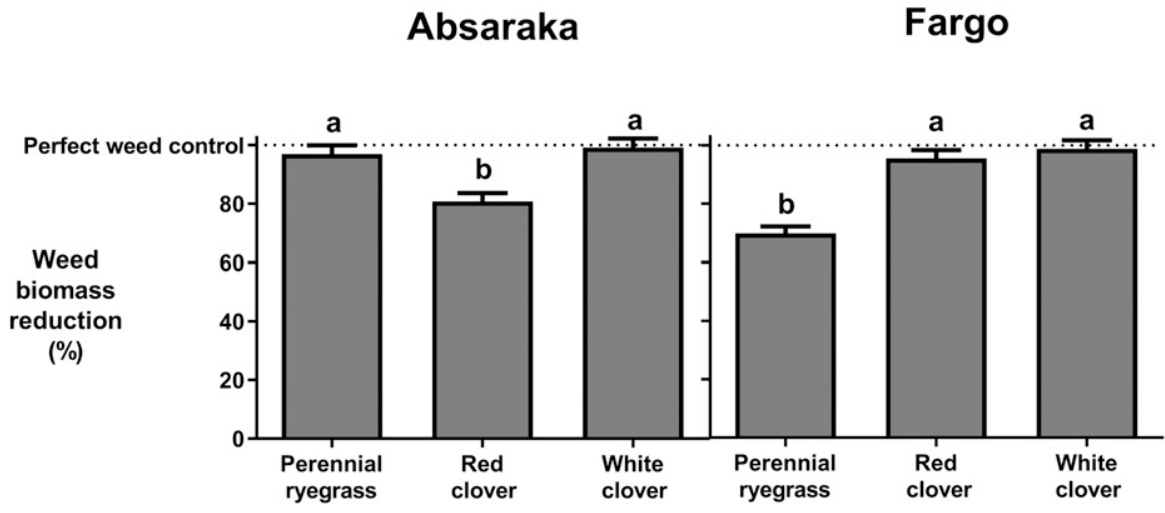

Fig. 4. Weed biomass percent reduction from the weedy control at peak biomass accumulation in the living mulch zone in Absaraka, ND, and Fargo, ND, in 2019. Living mulch zones were managed to support carrot growth in adjacent strip-till zones. Bars represent the mean, and error bars represent the SE. Bars with the same letters do not differ according to Tukey's honestly significant difference $(\alpha=$ 0.05).

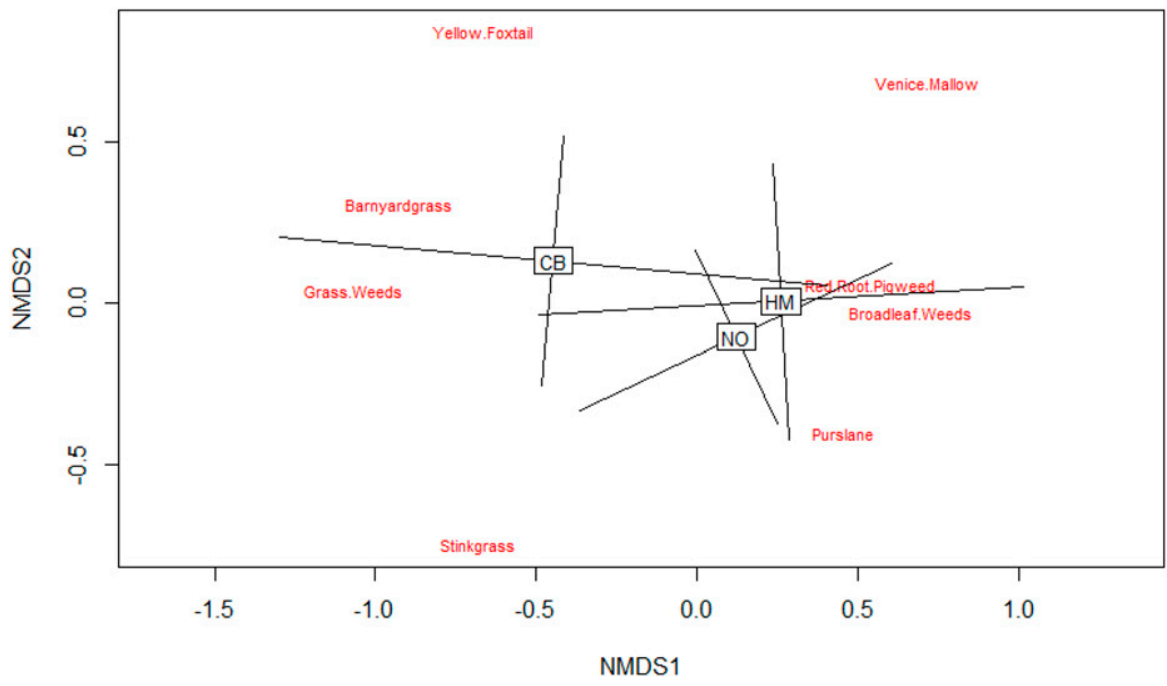

Fig. 5. Weed community ordination during peak biomass accumulation in the strip-till zone near Absaraka, ND, and in Fargo, ND, during 2018 and 2019. Strip-till zones were planted to carrot. Surface mulch treatments [compost blanket (CB), hydromulch (HM), and the no-mulch control (NO)] are fitted within the ordination. Unlike a principal component analysis, axes in nonmetric multidimensional scaling (NMDS) do not explain different amounts of variation and are only meant to show distance between the surface mulch treatments. An analysis of variance was conducted on this ordination and determined that the $C B$ weed community differed from the no-mulch and hydromulch weed communities $(P<0.05)$.

less than $10 \%$ of the total biomass reduction. Differences in weed control could explain the differences in carrot yield between the compost blanket and no-mulch control (Fig. $2)$, but the absence of a difference in yield between the hydromulch and no-mulch suggests that additional factors beyond weed control may allow for better carrot growth in compost blankets than hydromulch treatments. The compost blanket
0.11 and $0.17 \mathrm{~kg}$ N per strip-till zone; however, because the compost blanket was removed by hand rather than incorporated into the soil, the extent to which the compost blanket improved the fertility of the soil is unclear. Soil cores were not taken within the strip-till zone and therefore we are unable to comment on whether the compost blanket or hydromulch altered the fertility of the soil in the strip-till zone. The thickness of the compost blanket, and its ability to store water also may have contributed to the detectable difference in carrot biomass from the no-mulch control. Mulch modification of soil moisture and temperature, and the negative effect of living mulches on crop growth are well established (Braunack et al., 2020; O'Brien et al., 2018), but these responses could not be sufficiently quantified in this study. Compost blanket improvements to carrot yields compared with the no-mulch control were modest in comparison with the effect of living mulches on yield, but further investigation of the fertility, moisture, and temperature modifications provided by compost blanket may clarify the findings of this study.

SoIL. After 2 years of living mulch establishment, soils planted to white clover and red clover contained the greatest soil nitrate, whereas the weedy and weed-free control plots contained the least soil nitrate content (Fig. 8).

Greater soil nitrate content in clover treatments was expected, and the observed increase of $14 \mathrm{~kg} \cdot \mathrm{ha}^{-1}$ falls within a reasonable range of expectations for leguminous crops (Carlsson and Huss-Danell, 2003). Previous meta-analyses suggested red clover tends to fix more $\mathrm{N}$ than white clover, but a variety of additional factors contribute to $\mathrm{N}$-fixation rates between red and white clover such as biomass production and years in production. Our findings are not surprising because white clover treatments in this experiment appeared healthier and more productive throughout both growing seasons compared with the red clover treatments. A possible reason why the red clover treatments may not have appeared as vigorous was attributed to the tall growth habit that was less conducive to mowing (Ross et al., 2001). When living mulch treatments 


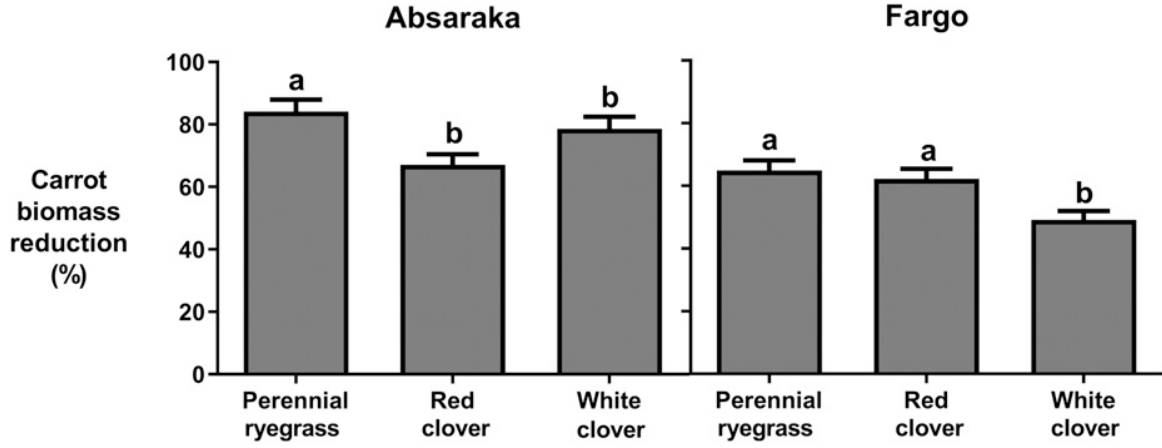

Fig. 6. Average carrot biomass reduction from the weed-free control in 2018 and 2019. Bars represent the mean, and error bars represent the SE. Bars with the same letters do not differ according to Tukey's honestly significant difference $(\alpha=$ $0.05)$.

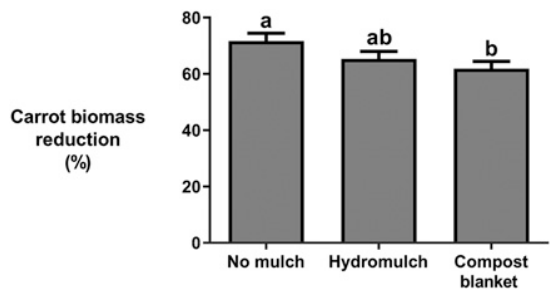

Fig. 7. Average carrot biomass reduction from the weed-free control among surface mulch treatments in Absaraka, ND, and Fargo, ND, in 2018 and 2019. Bars represent the mean, and error bars represent the SE. Bars with the same letters do not differ according to Tukey's honestly significant difference $(\alpha=0.05)$.

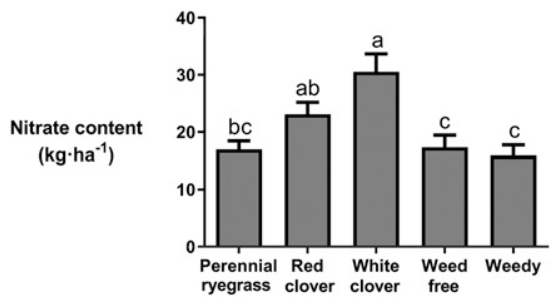

Fig. 8. Soil nitrate content among living mulch treatments after carrot harvest in 2019 in Absaraka, ND, and Fargo, ND. Bars represent the mean, and error bars represent the SE. To meet the assumption of normality, soil nitrate content was $\log$ transformed before mean comparisons and then back transformed for data presentation. Bars with the same letters are do not differ according to Tukey's honestly significant difference $(\alpha=0.05) ; 1$ $\mathrm{kg} \cdot \mathrm{ha}^{-1}=0.8922 \mathrm{lb} /$ acre .

were mowed for the first time in 2019, red clover treatments were $\approx 70 \mathrm{~cm}$ tall while white clover was $\approx 20 \mathrm{~cm}$ tall. After the initial mowing, red clover treatments did not grow back as vigorously as white clover, and stand density in red clover plots also appeared lower than the white clover plots, which may explain the lower levels of soil nitrate content and weed suppression observed. Ultimately, the data collected on soil response were very limited due to the preliminary nature of this experiment; however, our measurements suggest trends consistent with more comprehensive studies about soil health improvements associated with perennial living mulches.

\section{Conclusions}

Yield reduction associated with living mulches remains a significant barrier to their implementation for weed suppression in vegetable production. Further competition management strategies (i.e., wider strip-till zones, ridge planting, less competitive species) may be required for simultaneous living mulch and vegetable crop production without unacceptable yield reduction. Both surface mulches examined in this study provided sufficient increases in weed control and crop productivity to be of interest to both the grower collaborators in our research and to other growers and researchers at presentations of our results.

Although mulches are highly desirable tools in vegetable production, research rarely targets direct-seeded crops, resulting in a lack of improved cultural practices for crops such as carrot. Using newspaper hydromulches directly after thinning an overseeded crop or planting directly into a compost blanket could allow direct-seeded vegetable producers to access the benefits provided by mulches and enable diversification of weed control programs. Although we used newsprint in our experiment, any material or combination of materials that can be suspended in a liquid solution and harden after drying could be used. Post-consumer paper products are being evaluated for their ability to form a weed-suppressive hydromulch (Claramunt et al., 2020). We attempted to develop a management option for small-scale vegetable production in the Red River Valley of North Dakota, although there are likely applications beyond this environment.

\section{Literature cited}

Braunack, M.V., A. Zaja, K. Tam, L. Filipović, V. Filipović, Y. Wang, and K.L. Bristow. 2020. A sprayable biodegradable polymer membrane (SBPM) technology: Effect of band width and application rate on water conservation and seedling emergence. Agr. Water Manage. 230:105900, doi: 10.1016/j.agwat.2019.105900.

Carlsson, G. and K. Huss-Danell. 2003. Nitrogen fixation in perennial forage legumes in the field. Plant Soil 253:353372 .

Chase, C.A. and O.S. Mbuya. 2008. Greater interference from living mulches than weeds in organic broccoli production. Weed Technol. 22:280-285, doi: 10.1614/WT-07-119.1.

Claramunt, J., M.T. Mas, G. Pardo, A. Cirujeda, and A.M.C. Verdu. 2020. Mechanical characterization of blends containing recycled paper pulp and other lignocellulosic materials to develop hydromulches for weed control. Biosyst. Eng. 191:35-47, doi: 10.1016/j. biosystemseng.2019.12.012.

Clarke, K.R., P.J. Somerfield, and M.G. Chapman. 2006. On resemblance measures for ecological studies, including taxonomic dissimilarities and a zero-adjusted Bray-Curtis coefficient for denuded assemblages. J. Exp. Mar. Biol. Ecol. 330:5580, doi: 10.1016/j.jembe.2005.12.017.

DeDecker, J.J., J.B. Masiunas, A.S. Davis, and C.G. Flint. 2014. Weed management practice selection among midwest U.S. organic growers. Weed Sci. 62:520-531, doi: 10.1614/ws-d-13-00138.1.

Faith, D., P. Minchin, and L. Belbin. 1987. Compositional dissimilarity as a robust measure of ecological distance. Vegatatio 69:57-68.

Faucette, L.B., L.M. Risse, C.F. Jordan, M.L. Cabrera, D.C. Coleman, and L.T. 
Wes. 2006. Vegetation and soil quality effects from hydroseed and compost blankets used for erosion control in construction activities. J. Soil Water Conserv. 61:355-362.

Goldberger, J.R., R.E. Jones, C.A. Miles, R.W. Wallace, and D.A. Inglis. 2015. Barriers and bridges to the adoption of biodegradable plastic mulches for US specialty crop production. Renew. Agr. Food Syst. 30:143-153, doi: 10.1017/ S1742170513000276.

Gruszecki, R., A. Borowy, A. Sałata, and G. Zawiślak. 2015. Effect of living mulch and linuron on weeds and yield of carrot under ridge cultivation. Acta Sci. Pol. Hortorum Cultus 14:67-82.

Jerkins, D. and J. Ory. 2016. National organic research agenda. 15 Oct. 2019. <https://ofrf.org/wp-content/uploads/ 2019/09/NORA_2016_final9_28.pdf>.

Kołodziejczyk, M. 2015. The effect of living mulches and conventional methods of weed control on weed infestation and potato yield. Scientia Hort. 191:127-133, doi: 10.1016/j.scienta.2015.05.016.

Kołota, E. and K. Adamczewska-Sowińska. 2013. Living mulches in vegetable crops production: Perspectives and limitations (a review). Acta Sci. Pol. Hortorum Cultus 12:127-142, doi: 10.17660/ ActaHortic.2004.638.27.

Masiunas, J.B. 1998. Production of vegetables using cover crop and living mulches - A review. J. Veg. Crop. Prod. 4:11-31, doi: 10.1300/J068v04n01_03.

Miles, C., L. DeVetter, S. Ghimire, and D.G. Hayes. 2017. Suitability of bio- degradable plastic mulches for organic and sustainable agricultural production systems. HortScience 52:10-15, doi: 10.21273HORTSCI11249-16.

O'Brien, P.L., U. Acharya, R. Alghamdi, A.R. Niaghi, D. Sanyal, J. Wirtz, A.L.M. Daigh, and T.M. DeSutter. 2018. Hydromulch application to bare soil: Soil temperature dynamics and evaporative fluxes. Agr. Environ. Lett. 3:1-5, doi: 10.2134/ael2018.03.0014.

Oksanen, J., F. Blanchet, R. Kindt, P. Legendre, R. O'Hara, G. Simpson, P. Solymos, M. Stevens, and H. Wagner. 2010. Vegan: Community ecology package. R Package v 1:17-2. 10 Nov. 2019. <https://cran.r-project.org/package $=$ vegan $>$.

Osipitan, O.A., J.A. Dille, Y. Assefa, and S.Z. Knezevic. 2018. Cover crop for early season weed suppression in crops: Systematic review and meta-analysis. Agron. J. 110:2211-2221, doi: 10.2134/agronj2017. 12.0752 .

Pieper, J.R., R.N. Brown, and J.A. Amador. 2015. Effects of three conservation tillage strategies on yields and soil health in a mixed vegetable production system. HortScience 50:1770-1776.

Pfeiffer, A., E. Silva, and J. Colquhoun. 2016. Living mulch cover crops for weed control in small-scale applications. Renew. Agr. Food Syst. 31:309-317, doi: $10.1017 /$ S1742170515000253.

Reid, J.B., A.G. Hunt, P.R. Johnstone, B.P. Searle, and L.K. Jesson. 2018. On the responses of carrots (Daucus carota L.) to nitrogen supply. N. Z. J. Crop
Hort. Sci. 46:298-318, doi: 10.1080/ 01140671.2017 .1402790 .

Ross, S.M., J.R. King, R.C. Izaurralde, and J.T. O'Donovan. 2001. Weed suppression by seven clover species. Agron. J. 93:820-827, doi: 10.2134/agronj2001. 934820x

Schabenberger, O. 2005. Introducing the glimmix procedure for generalized linear mixed models. SUGI 30 Proc:1-20. 2 Dec. 2019 . <http://nesug.org/ proceedings/nesug05/an/an4.pdf $>$.

Swanton, C.J., J. O'Sullivan, and D.E. Robinson. 2010. The critical weed-free period in carrot. Weed Sci. 58:229-233, doi: 10.1614/ws-09-098.1.

Teasdale, J.R. and C.L. Mohler. 2000. The quantitative relationship between weed emergence and the physical properties of mulches. Weed Sci. 48:385-392.

Vendrell, P.F. and J. Zupancic. 1990. Determination of soil nitrate by transnitration of salicylic acid. Commun. Soil Sci. Plant Anal. 21:1705-1713.

Warnick, J., C.A. Chase, E. Rosskopf, E. Simmonne, J. Scholberg, R. Koenig, and N. Roe. 2006. Weed suppression with hydramulch, a biodegradable liquid paper mulch in development. Renew. Agr. Food Syst. 21:216-223.

Wortman, S.E., I. Kadoma, and M.D. Crandall. 2016. Biodegradable plastic and fabric mulch performance in field and high tunnel cucumber production. HortTechnology 26:148-155, doi: 10 . 21273/horttech.26.2.148. 